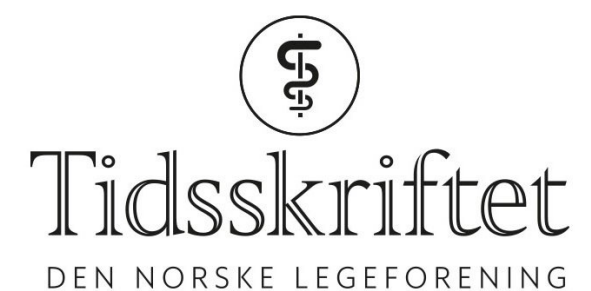

DEN NORSKE LEGEFORENING

\title{
Blodforyngelse og medisinens mål
}

KOMMENTAR

\section{HANS ERIK HEIER}

E-post: heheier@online.no

Hans Erik Heier er professor emeritus i transfusjonsmedisin fra Universitetet i Oslo og Oslo universitetssykehus.

Oppgitte interessekonflikter: Forfatteren har i 2017 gitt råd til firma CSL Behring om tekst i Felleskatalogen for et plasmaprodukt.

Artikkelen til Hofmann \& Olaussen om blodforyngelse er utfordrende og viktig og reiser både faglige og etiske spørsmål (1). Ett av dem er: Hva er helsetjenestens mål? Det undrer meg at dette og lignende spørsmål så sjelden drøftes i faglige fora. Tidligere helseminister Tore Tønne sa i et foredrag på Forum for helseadministrasjon i januar 2002, sitert fritt etter hukommelsen, at helsetjenesten handler om å gi menneskene gode liv. Det er et godt, men også diffust svar. Vi trenger å presisere svaret.

Professor Ole Berg sa i en personlig samtale til meg nylig at når menneskene har mistet håpet om et liv etter dette, vil de strebe etter paradis og evig liv på jorden. Er det blitt medisinens mål? I så fall må naturvitenskapen gis frie tøyler, og det kommersielle markedet vil gripe alle muligheter. Men da bør vi huske hva arkitekt Sverre Fehn skal ha sagt for mange år siden, at naturvitenskapen har gitt oss intetheten og tatt fra oss evigheten.

Naturvitenskapen kan ikke svare på menneskenes eksistensielle spørsmål, på de store spørsmålene om liv og død, heller ikke i samarbeid med markedet. Det er på tide med refleksjon om medisinens og naturvitenskapens grenser, og også om hvilke kilder vi kan bruke. Skal f.eks. navlestrengsblod kunne brukes, evt. selges, som kilde til foryngelse? Skal vi bruke forskningsmessige og industrielle ressurser på å renfremstille foryngelsesfaktorer i blod, evt. med genteknologi? Hvor langt vil vi la medisinen bli kommersialisert uten hensyn til etiske konsekvenser?

Når skal eksistensielle og ressursmessige refleksjoner bli en del av medisinstudiet og av utdanningen av Lege i spesialisering? Kan f.eks. Kirken komme ut av rett-troenhetsskallet sitt og vise seg som en ressurs i slike spørsmål? Jeg ønsker meg en artikkelserie om slike spørsmål i Tidsskriftet. Helt nylig er en god begynnelse publisert (2), der det blant annet pekes på at vi igjen nærmer oss de totalitære ideologiers mål om å skape det ideelle mennesket. Men vi trenger mye mer debatt om dette. Bare gjennom langvarig og omfattende offentlig refleksjon er det mulig å komme fram til holdbare svar som også må få politiske konsekvenser. 
2. Vogt H, Pahle A. Evig liv som medisinsk mål. Tidsskr Nor Legeforen 2017; 137: 1158 - 9.

[PubMed][CrossRef]

Publisert:30. oktober 2017. Tidsskr Nor Legeforen. DOI: 10.4045/tidsskr.17.0867

(C) Tidsskrift for Den norske legeforening 2020. Lastet ned fra tidsskriftet.no 